\title{
A systemic health risk assessment for the chromium cycle in Taiwan
}

\author{
Hwong-wen Ma*, Ming-Lung Hung, Pi-Cheng Chen \\ Graduate Institute of Environmental Engineering, National Taiwan University, 71 Chou-Shan Rd., Taipei 106, Taiwan
}

Received 24 May 2006; accepted 12 September 2006

Available online 30 October 2006

\begin{abstract}
Health risk assessment (HRA) has been recognized as a useful tool for identifying health risks of human activities. In particular, this method has been well applied to spatially defined units, such as a production plant, a treatment facility, and a contaminated site. However, the management strategies based on the risk information will be more efficient if the comprehensive picture of total risks from all kinds of sources is depicted. In principle, the total risks can be obtained when all risk sources are assessed individually. Apparently, this approach demands huge amount of efforts. This study develops a methodology that combines substance flow and risk estimation to facilitate examination of risk in a systemic way and provide comprehensive understanding of risk generation and distribution corresponding to flows of substances in the anthroposphere and the environment. Substance flow analysis (SFA) and HRA method is integrated to produce a systemic risk assessment method, from which substance management schemes can be derived. In this study, the chromium cycle in Taiwan is used as an example to demonstrate the method, by which the associated substance flow in the economy and the risk caused by the substance in the environmental system is determined. The concentrations of pollutants in the environmental media, the resultant risks and hazard quotients are calculated with the widely-used CalTOX multimedia model.
\end{abstract}

(C) 2006 Elsevier Ltd. All rights reserved.

Keywords: Health risk assessment; Substance flow analysis; Systemic; Chromium; CalTOX

\section{Introduction}

Health risk assessment (HRA) involves identifying the potential of a risk source to introduce risk agents into the environment, estimating the amount of risk agents that come into contact with the human-environment boundaries, and quantifying the health consequence of exposure. HRA consists of four steps: hazard identification, exposure assessment, dose/response assessment, and risk characterization (NRC, 1983). It entails the evaluation of the source, transport, fate, and exposure of chemicals of concern. The traditional risk assessment often focuses on examination of individual processes (see Fig. 1), such as emissions from factories (Newhook et al., 2003), discharges from waste treatment plants (Ma et al., 2002), and contamination of hazardous sites (Ma, 2002), and then evaluates relevant exposure pathways, which may involve water, air or food chain, to identify the risk posed by individual sources on human

\footnotetext{
* Corresponding author. Tel.: +886 2 23630406; fax: +886 223928830.

E-mail address: hwma@ntu.edu.tw (H. Ma).
}

receptors. However, the risk caused by the contaminated air does not originate from a single chimney only, and the groundwater pollution does not result from a single factory only; but they are caused by all kinds of human activities. Independent assessment of individual risk sources may not lead to efficient resource allocation; management measures derived from the individual assessments may even result in risk transfer between problems. Therefore a comprehensive view demands the systemic consideration of the risks of multiple processes from all human activities.

Substance flow analysis (SFA) is used to characterize substance stocks and flows within and between the economy and the environment in a certain time period and for a certain region (Guin'ee et al., 1999; Brunner and Rechberger, 2003). SFA is usually used to evaluate the environmental burdens at different stages related to specific substances' life-cycle. Many substance flows analyses have been carried out for various metals, including copper (Spatari et al., 2002, 2005; van Beers et al., 2003; Graedel et al., 2004; Vexler et al., 2004), cadmium (Van der voet et al., 1994; Lindqvist and von Malmborg, 2004; Hawkins et al., 2006), zinc (Palm et al., 1996; Spatari et al., 2003; Graedel et al., 2005a, b), silver (Johnson et al., 2005; Lanzano et al., 2006), and lead 


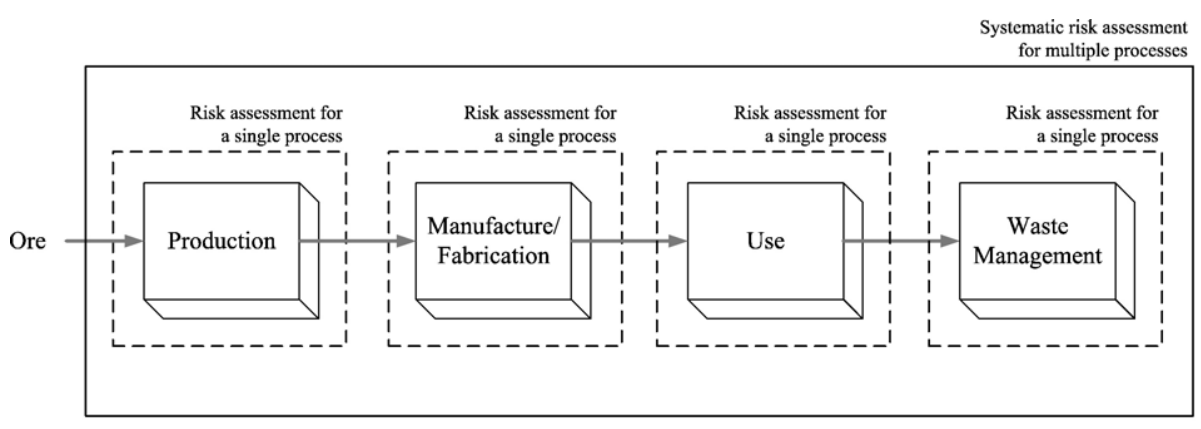

Fig. 1. The traditional risk assessment that focuses on individual processes. The traditional risk assessment often focuses on examination of individual process, and it is expected that the total risks can be obtained by considering all risk sources.

(Palm et al., 1996). Although SFA can estimate the flows for substances, it dose not provide information on the effect of the flows in the environment.

The flow of materials in the economy influences the flow in the environment. If the interflows between the economy and the environment are understood, the health impact from substances may be quantified through a systematic examination of the material flows. This study integrates the concept of SFA with HRA to establish a systematic and comprehensive risk assessment for the substance flows resulting from relevant processes at the substance's life stages from production to waste. The substance flow in the economy and the risk caused by the substance in the whole environmental system is determined by using the method. The chromium cycle in Taiwan is investigated as a case study.

\section{Chromium in the environment}

Chromium is widely used for various purposes. Chromium alloys have good performance in resisting acid aching and oxidation. Chromium-plated products have a mirror-like, brilliant surface. Ceramics containing chromium compounds can withstand high temperature and are called refractory. Chromium is also used in leather tanning, pigments, catalysts, etc. It is one of the most common contact allergy-causing substances for males in industrialized countries and is associated with occupational exposure to numerous materials and processes, including chrome plating baths, chrome colors and dyes, cement, tanning agents, wood preservatives, anticorrosive agents, welding fumes, lubricating oils and greases,

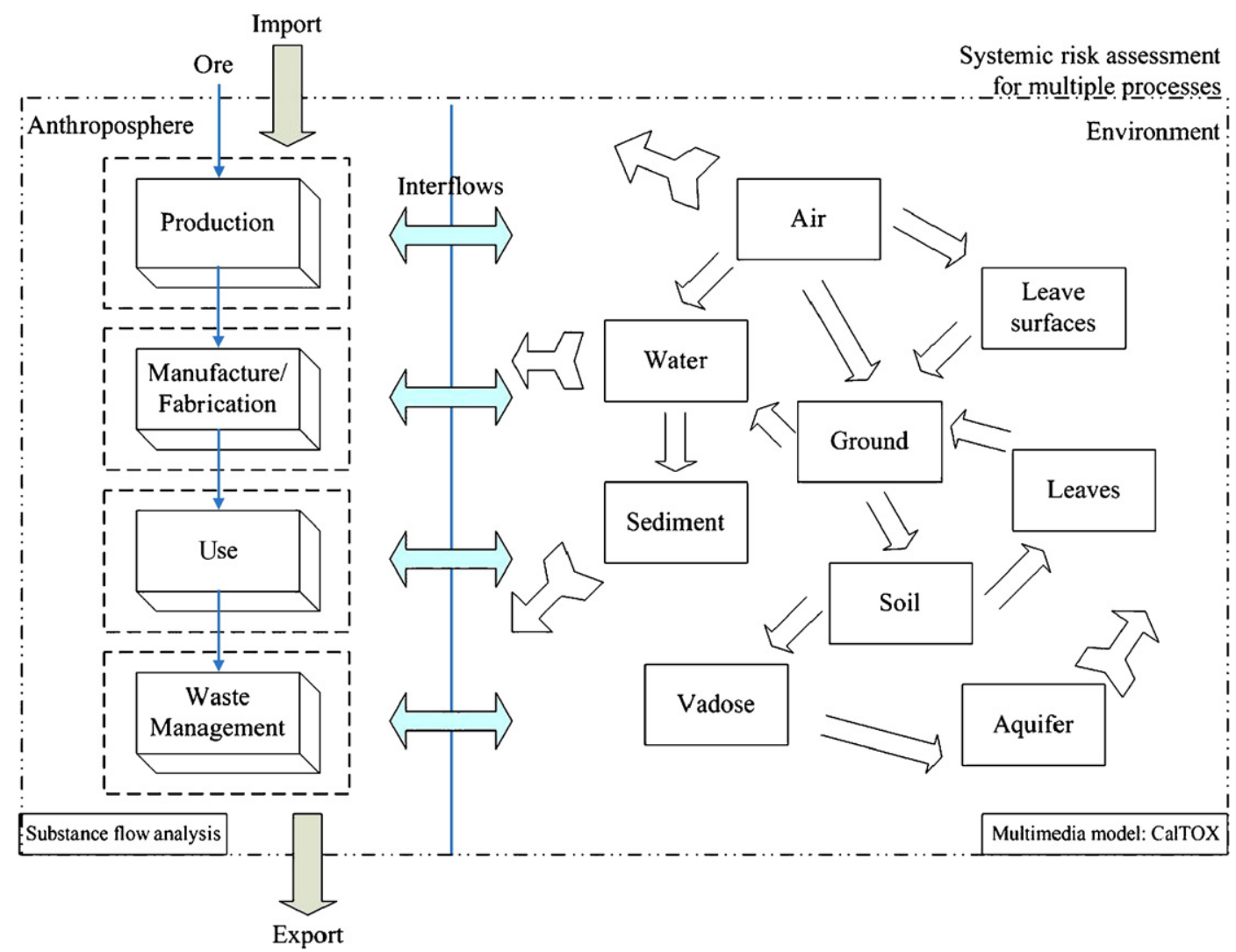

Fig. 2. The concept of integrating SFA and HRA. The flow of substances in the anthropogenic system and between this system and environmental system can be determined and then the transport and fate substances in the environment ant the resultant exposure and risk can be evaluated. The combination of SFA and HRA facilitates the examination of risk in a systematic way and deliveries a bigger picture. 


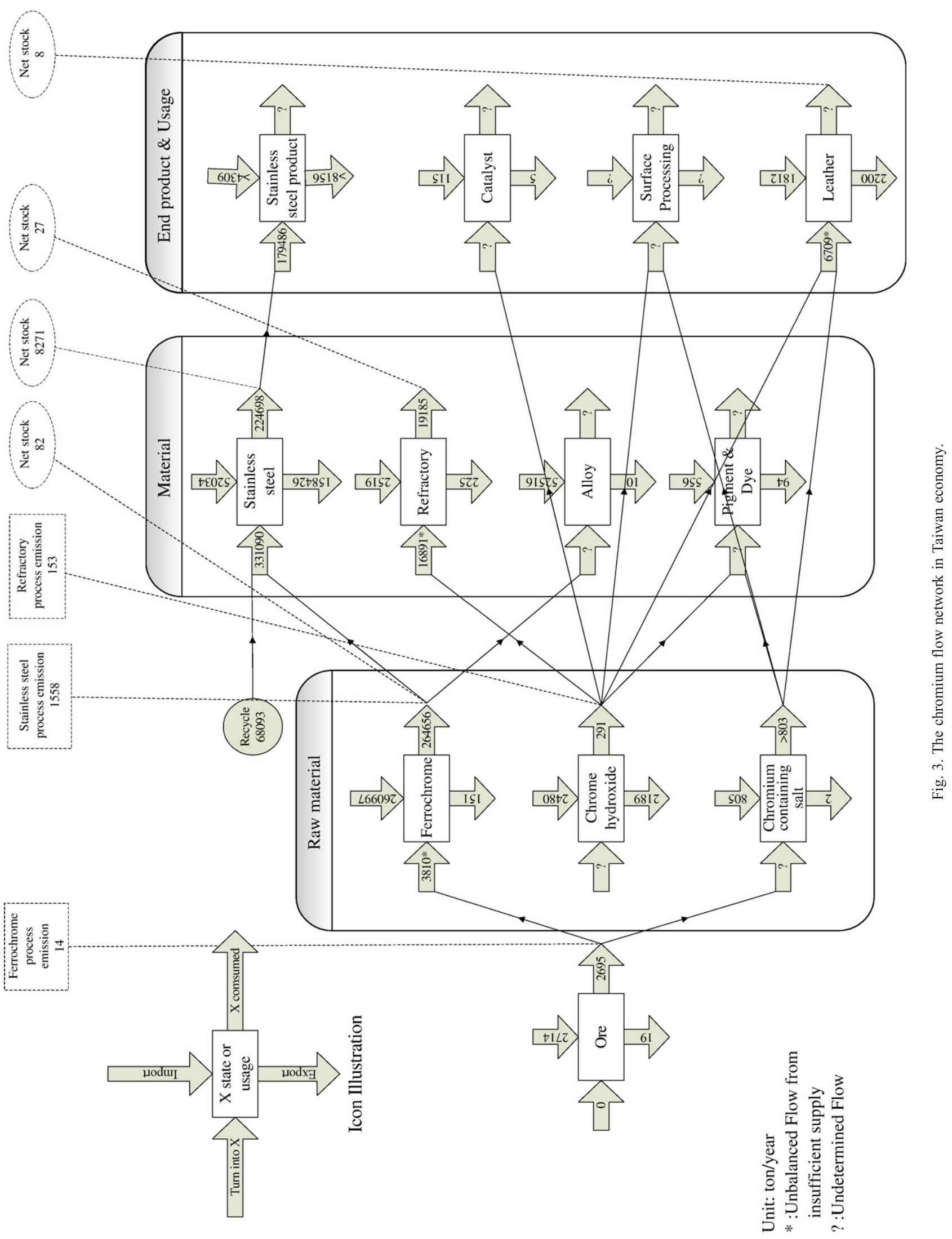


cleaning materials, textiles and furs (Polak, 1983; Burrows et al., 1990).

Chromium exists in multiple valence states, with trivalent chromium Cr (III) being the most common, which is also an essential nutrient for humans and other species. Hexavalent chromium $\mathrm{Cr}$ (VI), the second-most stable state, has been determined to be a human carcinogen by the route of inhalation. Ingesting large amounts of $\mathrm{Cr}$ (VI) can cause stomach upsets and ulcers, convulsions, and kidney and liver damage (ATSDR, 2000). Chromium is released into the environment in large amounts as a result of human activities, including air emissions from fuel combustion and metal industries, water discharges from

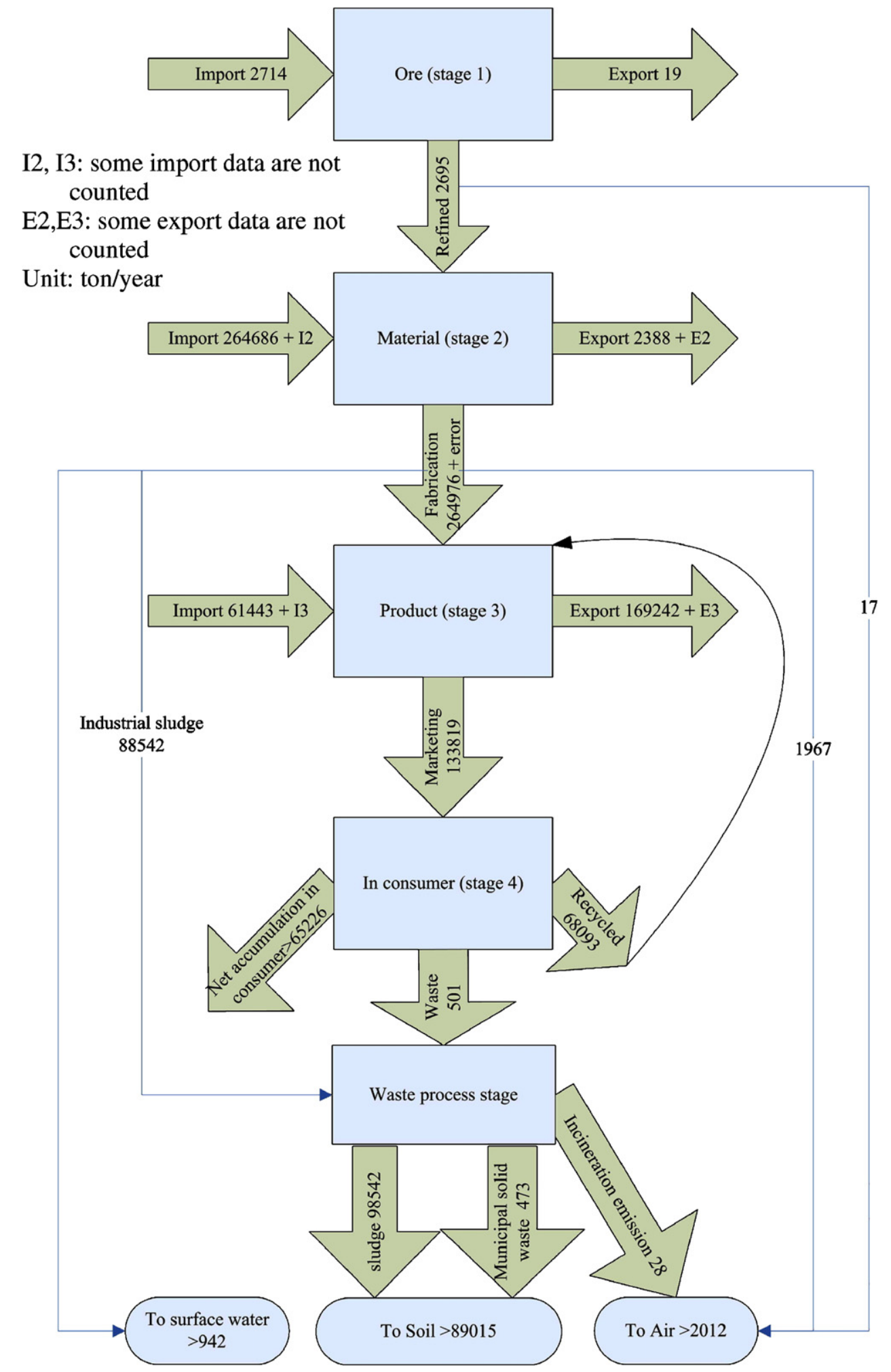

Fig. 4. The life stages type of chromium flow in Taiwan. 
electroplating, leather tanning, and textile industries, and soil contamination from disposal of $\mathrm{Cr}$-containing waste and sludge (Fishbein et al., 1981). Chromium has been found at 1036 of the 1591 National Priority List sites identified by the US EPA (ATSDR, 2000). In Taiwan, chromium is the major pollutant at 140 of the 576 hazardous sites listed by the Taiwan EPA (Taiwan EPA, 2006a). The issue of chromium contamination has made it rank fifth among the metals in the Comprehensive Environmental Response, Compensation, and Liability Act (CERCLA) priority list of hazardous substances (ATSDR, 2005).

$\mathrm{Cr}$ (VI) may exist in aquatic media as water-soluble complex anions and may persist in water. It is a strong, oxidizing agent and may react with organic matter or other reducing agents to form $\mathrm{Cr}$ (III), which will eventually be precipitated as $\mathrm{Cr}_{2} \mathrm{O}_{3} \cdot$ $x \mathrm{H}_{2} \mathrm{O}$. Therefore, in surface water rich in organic content, $\mathrm{Cr}$ (VI) exhibits a much shorter lifetime (ATSDR, 2000). Any $\mathrm{Cr}$ (VI) in the soil is expected to be reduced by organic matter to $\mathrm{Cr}$ (III). The primary processes through which the converted $\mathrm{Cr}$ (III) is lost from the soil are aerial transport through aerosol formation and surface water transport through runoffs (U.S. EPA, 1984). Very little chromium is leached from the soil because it is present as insoluble $\mathrm{Cr}_{2} \mathrm{O}_{3} \cdot x \mathrm{H}_{2} \mathrm{O}$ (Fishbein et al., 1981).

\section{An integrated risk assessment methodology}

Risk assessment has been recognized as a useful tool for identifying health risks of human activities. In particular, this method has been well applied to spatially defined units, such as a production plant, a treatment facility, and a contaminated site. Understanding the risk associated with an individual source is essential for designing measures to control the concerned source and related exposure pathways. However, the management strategies based on the risk information will be more efficient if the total risks from all kinds of sources are known. A comprehensive grasp of the risks from various activities can assist decision makers in allocating resources to manage the activities as well as avoid risk transfer between activities. In principle, the total risks can be obtained when all risk sources are assessed individually. Apparently, this approach demands huge amount of efforts. Another approach is based on substance management point of view. From this aspect, the flow of substances in the anthroposphere and between the human system and the environmental system should be sketched first. Then the transport and fate of substances in the environment and the resultant exposure and risk are evaluated. The combination of substance flow and risk assessment facilitates the examination of risk in a systemic way and provides comprehensive understanding of risk generation and distribution corresponding to flows of substances in the anthroposphere and the environment. This study attempts to integrate SFA and HRA method in order to produce an integrated environment risk assessment method, from which substance management schemes for reducing risks can be formulated. Fig. 2 illustrates the concept of integration.

\subsection{Substance flow analysis}

By characterizing substance flow in the economy and between human and environmental systems, SFA can identify important sources of hazardous substances released to waste streams and eventually, the environment. SFA frameworks have been defined in the literature (Baccini and Brunner, 1991; Van der Voet et al., 1999; Brunner and Rechberger, 2003), and $\mathrm{IN}=$ OUT is a simple statement of the central paradigm of SFA (Kleijn, 1999). The fundamental mass balance equation used in a system defined by temporal and spatial boundaries is as follows.

$$
\begin{aligned}
& \text { Import }+ \text { Production }+ \text { Recycling } \\
& \quad=\text { Export }+ \text { Accumulation }+ \text { Consumption }
\end{aligned}
$$

Two structures of substances flow are applied in this study. One is network type, and the other is life stage type.

\subsubsection{Network type of SFA}

The network type structure looks like a tree with branches extending from raw material to processed material, product and usage (see Fig. 3) (Ayres and Ayres, 1996). Every material or product is a node in the network. Each node has several inputs and outputs. These inputs and outputs must balance. In other words, the flow rates leaving from ore material or product must match the flow going to its destinations. Substances travel through different paths and destinations. From main stem to leaves, the path divides more and more, implying that the usages (product) of substances become more diverse toward the end of substances' life stages.

For the network structure, the first work after determining the system boundary is to identify the commodities containing the studied substance and define which stage a commodity item belongs to according to the life of the substances. Second, the interflows between commodities at different stages are evaluated by balancing the outputs with the inputs. Third, estimate how much material is released into the environment through various paths. These paths and flow rate estimations are discussed in the next section. Note that the outputs include material losses as pollution in every industrial process. These losses must be taken into the balance.

\subsubsection{Life stage type of SFA}

The life stage structure of SFA includes stages of ore mining, refined material, finished product, usage, and waste. Each stage includes various types of substances-containing commodities. The inputs and outputs of commodities belonging to the same life stage is combined together to form a main current (see Fig. 4). Compared with network structure, it is less complex because commodities of the same stage are deemed as a system unit. It describes how substances are transformed from ore to product and waste. The mass balance of each life stage of a substance within a system identified by temporal and spatial boundaries (the temporal boundary is $1 \mathrm{yr}$ and the spatial boundary is the Taiwan island in the case study is described as follows:

Stage 1 - raw material stage:

$$
\begin{aligned}
\text { Ore import }= & \text { Ore export } \\
& + \text { Transformation into stage } 2 \text { materials } \\
& + \text { Loss from industrial processes }+ \text { Stock }
\end{aligned}
$$


Stage 2 - processed material stage:

Transformation into stage 2 materials from stage 1 raw materials + Import of stage 2 materials

+ Recycled stage 2 materials

$=$ Export of stage 2 materials

+ Transformation into stage 3 products

+ Loss from industrial processes + Stock

Stage 3 - product stage:

Transformation into stage 3 products from stage 2 materials

+Import of stage 3 products

+ Recycled stage 3 products

$=$ Export of stage 3 products

+Flow into stage 4 consumer sector

+ Loss from industrial processes + Stock

Stage 4 - consumer use stage:

Flow into stage 4 from stage 3 products

$=$ Net stock in the economy

+ Wasted stage 4 consumer products

+ Recycled to previous stages

The losses from industrial processes include air emissions, wastewater effluents, solid waste and sludge. The waste management processes involve landfilling and incineration of materials and products, taking into account of the associated releases to the environment.

\subsection{The releases of substances into the environment}

\subsubsection{Air emissions}

The industrial emissions into air can be estimated by the emission factor method (EF). The method assumes that the emission amount is proportional to the magnitude of industrial activities in an ideal condition. The magnitude has several definitions which must correspond to the EF. The EF corresponding to raw material consumption rate is used in this study; and therefore the unit of $\mathrm{EF}$ is $\mathrm{kg}$ emission/ton raw material. The EF information is derived from the U.S. EPA document (U.S. EPA, 1984) and survey of Danish EPA (Danish EPA, 2003).

The main air emission sources in the chromium cycle are the production processes of ferrochrome, stainless steel, and refractory, and the processes of waste incineration and coal and fossil fuel burning. The flow rates are estimated by the following equations:

$Q_{i}=P_{i} \times \mathrm{EF}_{i}$

$i=$ ferrochrome, stainless steel, refractory

$Q_{\text {incinerator }}=W$ burnwaste $\times \mathrm{EF}_{\text {incinerator }}$

$Q_{i}=E_{i} \times \mathrm{EF}_{i}$

$i=$ coal, oil

\subsubsection{Surface water discharges}

The estimation of effluent into water is difficult. It costs too much to monitor all effluent sources. The alternative method is to compare concentrations of substances in water bodies with background concentrations.

In a polluted river, all $\mathrm{Cr}$ effluents are collected near the estuary except for some that were caught by sediments or drawn out for certain usages such as irrigation. If the $\mathrm{Cr}$ flow in the watershed has reached a steady state, a phenomenon that will appear is that the quantity of $\mathrm{Cr}$ discharged into the water will equal that which instills into the sea. Although the real condition is not a steady state, the Cr discharged into the sea will roughly reflect that discharged into the watershed. The $\mathrm{Cr}$ carried by water flow is estimated as follows:

$Q_{\text {surface water }}^{j}=Q_{\text {flow rate }}^{j} \times C_{\text {soluble }}^{j} \times T$

$Q_{\text {surface water }}=\sum_{j} Q_{\text {surface water }}^{j}$

\subsubsection{Soil releases}

The release of $\mathrm{Cr}$ into the soil includes consideration of incineration ash, landfilled waste, and industrial sludge. The method can be estimated through multiplying the weight of the waste and its $\mathrm{Cr}$ content. The data can be derived from the Taiwan EPA registered waste information (Taiwan EPA, 2006b).

$S_{i}=C_{i} \times W_{i}$

$i=$ fly ash, bottom ash, landfill

The data source of industrial sludge is obtained from the Taiwan EPA, and the industrial sludge is divided into 19 categories. Each kind of sludge contains several heavy metal constituents, for example, chromium, copper and lead. Because of limited information on the contents of specific metals, the quantity of $\mathrm{Cr}$ in industrial sludge is approximated as follows:

$\begin{aligned} Q_{\text {sludge }}^{i}= & \frac{W_{\text {sludge }}^{i}}{N^{i}}\left[X_{\mathrm{Cr}} \times C_{\mathrm{Cr} \text { sludge }}+X_{\mathrm{Cu}} \times C_{\mathrm{Cu} \text { sludge }}\right. \\ & \left.+X_{\mathrm{Pb}} \times C_{\mathrm{Pb} \text { sludge }}\right]\end{aligned}$

The total amount of $\mathrm{Cr}$ in the registered sludge can then be summed as follows:

$Q_{\text {sludge }}=\sum_{i} Q_{\text {sludge }}^{i}$

\subsection{Risk assessment modeling}

After the substance flow for each process has been determined by SFA, HRA can then be used to calculate the risks for all the processes related to the substance. In this study, the concentrations of pollutants in the media, resultant risk, and hazard quotients are calculated with the widely-used CalTOX (v4.0) multimedia risk assessment model, developed for the U. 
Table 1

The import, export and production quantities of various chromium commodities in Taiwan

\begin{tabular}{|c|c|c|c|c|c|c|}
\hline Name & Life stage & Import (t/yr) & Contribution $(\%)$ & Output (t/yr) & Contribution $(\%)$ & Production $(\mathrm{t} / \mathrm{yr})$ \\
\hline Chromium Ore & 1 & 2713.7 & 0.71 & 19.0 & 0.01 & \\
\hline $\mathrm{Cr}_{2} \mathrm{O}_{3}$ & 2 & 1598.7 & 0.42 & 86.2 & 0.05 & \\
\hline Other chromium oxide & 2 & 835.6 & 0.22 & 33.1 & 0.02 & \\
\hline $\mathrm{Cr}(\mathrm{OH})_{3}$ & 2 & 0.2 & 0.00 & 0.0 & 0.00 & \\
\hline Chromium sulfate & 2 & 45.4 & 0.01 & 2069.9 & 1.21 & \\
\hline $\mathrm{ZnCrO}_{4}$ & 2 & 1.9 & 0.00 & 0.0 & 0.00 & \\
\hline $\mathrm{PbCrO}_{4}$ & 2 & 24.8 & 0.01 & 0.0 & 0.00 & \\
\hline $\mathrm{Na}_{2} \mathrm{Cr}_{2} \mathrm{O}_{7}$ & 2 & 747.2 & 0.20 & 2.0 & 0.00 & \\
\hline $\mathrm{K}_{2} \mathrm{Cr}_{2} \mathrm{O}_{7}$ & 2 & 31.3 & 0.01 & 0.0 & 0.00 & \\
\hline Ferrochrome & 2 & 260977.2 & 68.44 & 151.2 & 0.09 & 3810.6 \\
\hline Unshaped chromium & 2 & 371.7 & 0.10 & 35.4 & 0.02 & \\
\hline Chromium alloy & 2 & 52516.5 & 13.77 & 10.2 & 0.01 & \\
\hline Chrome alum & 3 & 0.0 & 0.00 & 0.0 & 0.00 & \\
\hline Chrome yellow & 3 & 555.7 & 0.15 & 94.5 & 0.06 & \\
\hline Tanned leather & 3 & 1812.3 & 0.48 & 2200.1 & 1.28 & 6719.2 \\
\hline Refractory & 3 & 2519.1 & 0.66 & 225.7 & 0.13 & 16891.4 \\
\hline Chromium article & 3 & 98.2 & 0.03 & 133.7 & 0.08 & \\
\hline Catalyst & 3 & 114.8 & 0.03 & 5.2 & 0.00 & \\
\hline Stainless steel & 3 & 52034.3 & 13.65 & 158426.6 & 92.30 & 331090.3 \\
\hline Vehicle & 3 & 211.8 & 0.06 & 145.6 & 0.08 & \\
\hline Machine & 3 & 3885.1 & 1.02 & 7710.7 & 4.49 & \\
\hline tool & 3 & 212.4 & 0.06 & 300.4 & 0.18 & \\
\hline Stainless steel product & 3 & 4309.4 & 1.13 & 8156.7 & 4.75 & \\
\hline Chromate salts & 2 & 805.1 & 0.21 & 2.0 & 0.00 & \\
\hline Chromium oxides & 2 & 2434.5 & 0.64 & 119.2 & 0.07 & \\
\hline
\end{tabular}

Note: the life stages 1, 2, and 3 refer to ore, material, and product stages, respectively.

S. California EPA (DTSC, 1993). The model combines multimedia transport and transformation modeling of pollutants in the environment and multiple pathway exposure modeling. This model is chosen because it is suitable for modeling regional environmental transfer between environmental media. The environment is separated into several compartments, including air, plants, surface water, ground water, sediment, ground-surface soil, root-zone soil, and vadose-zone soil.

The valence of chromium changes with the environmental conditions (redox potential and $\mathrm{pH}$ value). If the environment is under higher oxidation potential or $\mathrm{pH}, \mathrm{Cr}$ (III) tends to be transformed to $\mathrm{Cr}$ (VI), which is more toxic. Because of difference of toxicity, the risks of $\mathrm{Cr}$ (VI) and $\mathrm{Cr}$ (III) must be estimated separately and then are summed to give a total $\mathrm{Cr}$ risk. For $\mathrm{Cr}$ in ambient air, Canadian studies (Government of Canada, 1994) show that $\mathrm{Cr}$ (VI) accounted for between 3\% and $8 \%$ of the total chromium in ambient air with the remainder in $\mathrm{Cr}$ (III) form. Therefore, this study takes $6 \%$ as the portion of $\mathrm{Cr}$ (VI) in ambient air. In water, the soluble chromium compounds are $\mathrm{Cr}(\mathrm{VI})$, but some $\mathrm{Cr}$ (VI) are reduced to $\mathrm{Cr}$ (III). The $\mathrm{Cr}$ (III) becomes insoluble sediment. In this study, all the $\mathrm{Cr}$ contents of rivers are set as soluble $\mathrm{Cr}$ (VI) forms. In soil, $\mathrm{Cr}$ (VI) is easily reduced to $\mathrm{Cr}$ (III), because organic compounds tend to be oxidized by $\mathrm{Cr}$ (VI) (ATSDR, 2000). Generally, people intake chromium from the soil through organisms (food) or dust, which comes from the ground surface, where there is an abundance of organic matter. Therefore, it is acceptable to assume that all $\mathrm{Cr}$ uptakes from soil are $\mathrm{Cr}$ (III). In addition, the release rate of $\mathrm{Cr}$ from the solidified sludge is estimated $5 \%$ based on a leaching test (Taiwan EPA, 2002).
Cancer risk is characterized using lifetime excess cancer risk estimates to represent the excess probability of developing cancer over a lifetime as a result of exposure to the substance of interest. Lifetime excess cancer risk estimates are the product of the average daily dose (ADD) for a receptor group and the corresponding cancer slope factor. The cancer slope factor is derived from either human or animal data and is taken as the upper bound on the slope of the dose-response curve in the lowdose region, generally assumed to be linear, expressed as a lifetime excess cancer risk per unit exposure. The ADD can be calculated as follows:

$\mathrm{ADD}_{m n}=C_{m} \times \frac{\mathrm{IU}_{m n}}{\mathrm{BW}} \times \frac{\mathrm{EF} \times \mathrm{ED}}{\mathrm{AT}}$

Noncancer risk is characterized through the use of hazard quotients (HQ), which are computed by dividing an average daily dose by a reference dose $(\mathrm{RfD})$. The reference dose represents a

Table 2

Air emissions of different sources related to chromium commodities

\begin{tabular}{lclr}
\hline Source & Activity scale $(\mathrm{t})$ & Emission factor & Emission (t) \\
\hline Ferrochrome & 3811 & $0.00457^{\mathrm{a}}$ & 17.4 \\
Coal plant (GJ) & 353 & $0.802^{\mathrm{b}}$ & 283.2 \\
Oil plant (GJ) & 109 & $0.00221^{\mathrm{b}}$ & 0.2 \\
Refractory & 98751 & $0.00154681^{\mathrm{a}}$ & 152.7 \\
Stainless steel & 1947590 & $0.0008^{\mathrm{a}}$ & 1558.1 \\
Incinerator & 4316049 & $0.0000066^{\mathrm{b}}$ & 28.5 \\
Sum & & & 2011.7 \\
\hline
\end{tabular}

${ }^{a}$ U.S. EPA (1984).

b Danish EPA (2003). 
Table 3

The concentration of $\mathrm{Cr}$ and water content of different kinds of sludge

\begin{tabular}{lll}
\hline Kinds of sludge & The concentration of $\mathrm{Cr}$ & Water content $(\%)$ \\
\hline Pb-containing sludge & 0.0024 & 79.10 \\
Cu-containing sludge & 0.0238 & 74.30 \\
Cr-containing sludge & 0.331 & 26.40 \\
\hline
\end{tabular}

"no-effects" level that is presumed to be without appreciable risk from chronic exposures over a lifetime. An HQ establishes whether a receptor has experienced exposure above or below a threshold of concern for a specific health effect (U.S. EPA, 1999).

\section{Estimated chromium flows in Taiwan}

The case studied is the chromium flow in Taiwan in year 2002 and the spatial boundary encompasses the whole Taiwan Island. The flow rate is counted in the unit of ton $\mathrm{Cr} / \mathrm{yr}$. Several important Cr-containing commodities are identified and their flow information surveyed. Limited by the incomplete database, some items are not counted. A commodity is taken as a node in the network structure. The import and production of a commodity are the two inputs of a node, and the export and the fabrications (or consumption) that turn a commodity into other commodities are the outputs. The import and export data are extracted from the statistics of the Bureau of Foreign Trade (Bureau of Foreign Trade, 2005). The production and fabrication information is obtained from the Industrial Development Bureau (IDB, 2006).

Some information needed in our network is lacking. Some commodities are recorded as the summation of one category in which not all commodities contain $\mathrm{Cr}$. Yet the data do not indicate the percentage of Cr-containing commodities. It is also probable that some illegal imports may have not been counted in the database. Faced with these problems, what we could use is the mass balance principle for checking. In an ideal situation (no accumulation in the stock; all materials are either exported or fabricated in the year), the summation of all inputs must balance with the outputs. With the help of mass balance checking, some flow direction without data can be evaluated, and certain data errors can be identified.

Table 1 1shows input, export and production quantities of various chromium commodities in Taiwan. There is no ore mining of chromium in Taiwan; all the chromium ores are imported. $\mathrm{Cr}$ containing commodities are categorized into three main life stages-ore, material, and product. Ferrochrome accounts for $68.44 \%$ of the total imports. On the other side, stainless steel dominates $92.3 \%$ of the total export. Both ferrochrome and stainless steel are important metallurgy industry materials. Therefore, monitoring and controlling the flows into the metallurgy industry is essential to chromium resource management. These flow rates are fed into the substance flow network. The results are shown in Fig. 3. Fig. 4 shows the life stage type of chromium flows in Taiwan.

Several supplies and consumptions do not match. If the sum of the consumptions of the material to be produced is greater than the material supplied from the father node, there should be something incorrect in the data. Perhaps the data of $\mathrm{Cr}$ composition are not accurate for some commodities, or the supplied materials are not all registered in the statistics, or that some recycled or reused material has substituted for part of the supply. The amount of recycled stainless steel is estimated by this insufficient supply because the statistic of recycled stainless steel data was not available in 2002. If the supply is greater than consumption, there may be minor consumption that is not considered. The following indicators provide the aggregated information of chromium flow:

Domestic Material Input $(D M I)=\operatorname{Import}=328845 \mathrm{t}$

Domestic Material Consumption $(D M C)=$ Import - Export $=$ $157196 \mathrm{t}$

Net Additional to Stock $(N A S)=$ Import - Export - Release to

Environment (Ash from incineration + Landfill+effluents to surface water + industrial sludge + emission $)=65227 \mathrm{t}$

Domestic Processed Output $(D P O)=\mathrm{DMC}-\mathrm{NAS}=91969 \mathrm{t}$

Domestic Material Output $(D M O)=\mathrm{DPO}+$ Export $=263618 \mathrm{t}$

\section{The risk of the chromium flows in Taiwan}

\subsection{Chromium in the environment}

There are several main sources by which chromium is released into the air, including ferrochrome production, refractory production, stainless steel production, coal and fossil fuel burning, and incineration. The emission factors and the amount of emissions of these chromium release sources are displayed as Table 2. The sum of flows that can be estimated for the air is about 2012 t. For surface water, the $\mathrm{Cr}$ (VI) concentrations range from 0.012 to $0.646 \mathrm{mg} / \mathrm{L}$ in the 16 rivers that are significantly polluted. These rivers are mostly located at the middle or south of the west coast. These Cr-containing effluents originate from the upriver area where there are dense plating, dying, leather tanning, and waste metal processing factories. The total $\mathrm{Cr}$ flow into surface water is estimated about 942 t. Four paths of releasing $\mathrm{Cr}$ into the soil are considered. These are fly ash and bottom ash from incineration, solidified industrial sludge, and municipal solid waste that is landfilled directly without incineration. The amount of bottom ash and fly ash in Taiwan in year 2002 is $9.03 \times 10^{5} \mathrm{t}$ and $1.88 \times 10^{5} \mathrm{t}$, respectively. The concentration of $\mathrm{Cr}$ in bottom ash and fly ash is $207 \mathrm{mg} / \mathrm{kg}$ and $115 \mathrm{mg} / \mathrm{kg}$, respectively. The quantity of waste treated by direct landfilling is $6.72 \times 10^{6} \mathrm{t}$. The total $\mathrm{Cr}$

Table 4

Summary of main bulk flows of $\mathrm{Cr}$

\begin{tabular}{ll}
\hline & Cr flow(kg) \\
\hline Import & $3.29 \mathrm{E}+08$ \\
Export & $1.72 \mathrm{E}+08$ \\
Air emission & $2.01 \mathrm{E}+06$ \\
Surface water & $9.42 \mathrm{E}+05$ \\
Recycle & $6.81 \mathrm{E}+04$ \\
Ash from incineration & $2.09 \mathrm{E}+05$ \\
Landfill without incineration & $2.64 \mathrm{E}+05$ \\
Industrial sludge & $8.85 \mathrm{E}+07$ \\
\hline
\end{tabular}


into the soil is estimated about 89015 t. Table 3 shows the concentration of $\mathrm{Cr}$ and water content of different kinds of sludge. Table 4 summarizes the main bulk flows.

The intermedia transfer of $\mathrm{Cr}$ among various environmental media is shown in Fig. 5, based on a steady state assumption. In other words, it is assumed that there are no stocks or accumulations in the early three stages. For a large, long-term scale, it is acceptable to assume that, in the manufacturing process, the material transforms down into the next stage very fast (weeks or months), but a finished product may be used for years before it is discarded as waste.

\subsection{Risk characterization}

Tables 5 and 6 display the landscape and exposure parameters used in CalTOX in this study. The cancer risk and the HQ resulting from the total $\mathrm{Cr}$ flow are calculated as $7.6 \times 10^{-6}$ and 6.2 , respectively. Although with uncertainty discussed later, the result suggests that people in Taiwan may be under the threat of chromium health risk. It is of even greater concern if the underground release of $\mathrm{Cr}$ reaches an amount that cannot be ignored. To reduce the risk, the flow in the economy and the interflow between the economy and the environment should be controlled. Management measures include improvement of industrial processes to reduce use or consumption of $\mathrm{Cr}$ and utilization of more effective technologies to reduce emission, release, and discharge of $\mathrm{Cr}$ into the environment. If only a single release medium is considered, it can be backcalculated that the loading corresponding to risk of $10^{-6}$ is $2.64 \times 10^{5} \mathrm{~kg} / \mathrm{yr}$ of air emissions of $\mathrm{Cr}$, or $8.86 \times 10^{9} \mathrm{~kg} / \mathrm{yr}$ of soil releases of $\mathrm{Cr}$. The loading corresponding to HQ of 1 is $5.01 \times 10^{5} \mathrm{~kg} / \mathrm{yr}$ of air emissions of $\mathrm{Cr}$, or $4.48 \times 10^{8} \mathrm{~kg} / \mathrm{yr}$ of soil releases of $\mathrm{Cr}$.

\subsection{Regional redistribution}

The environmental flows in the model seem like a bulk flow which is distributed over any spots of Taiwan. The simulation result indicates an average value of risk and hazard quotient for Taiwan. However, the reality is that some areas may be faced with greater risk than the estimated average value and some areas lower. Although the big picture of risk associated with the substance flow has been depicted, it is of greater help if the areas with highest risk potential can be located. To do so, regional substance flow is required to characterize the regional differences of the risk. In this study, the administration division (county or city) is chosen as the smaller spatial unit because of its data accessibility. However, the data for the administration divisions are not as complete as those of the national scale.

Under the situation that the data is not sufficient to estimate the substance flow in the administration zones, the bulk flow has to be divided and assigned to the administration divisions. Some simplified assumptions are made in this case. First, there is no interflow between divisions; each division is seen as an

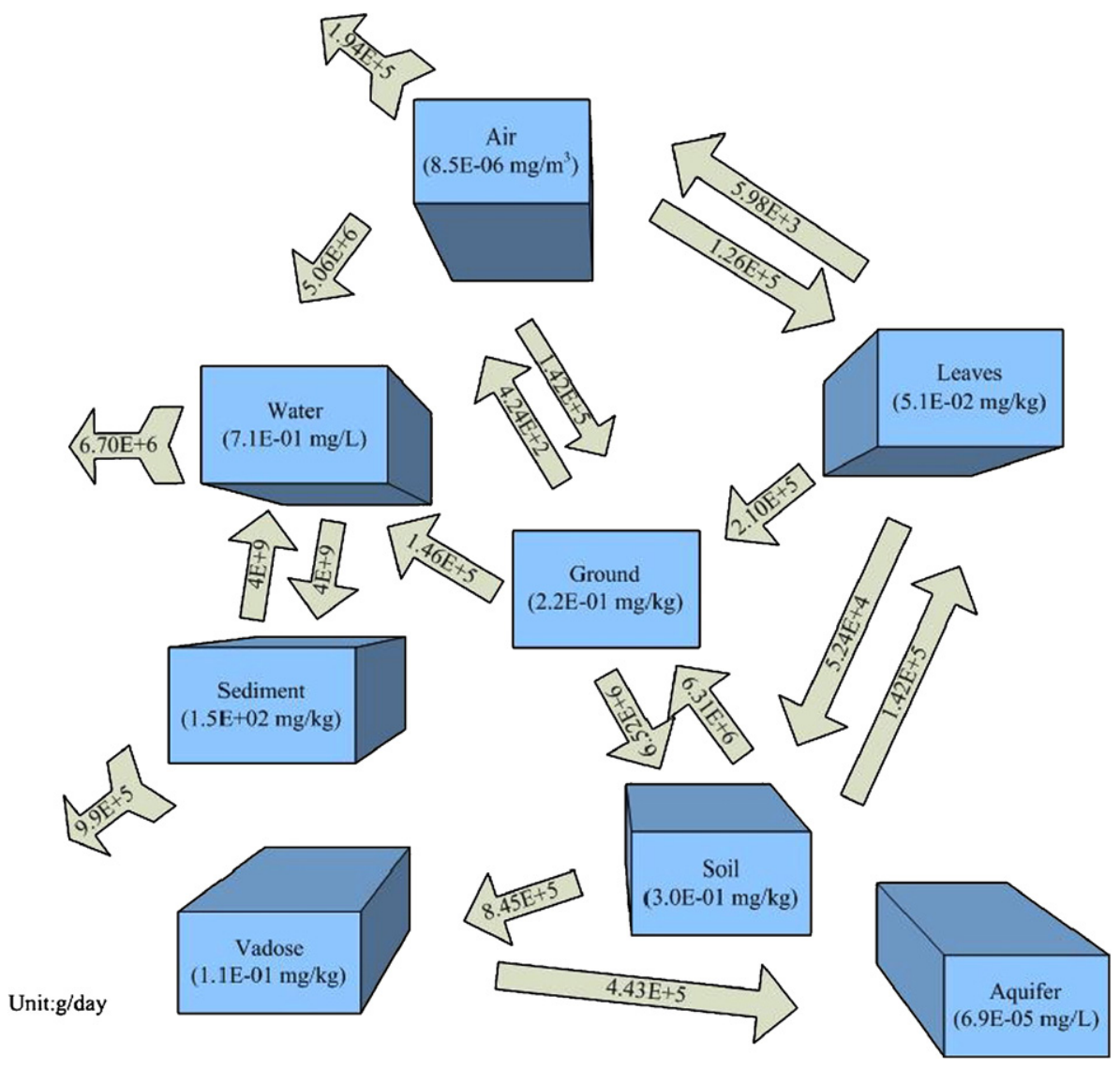

Fig. 5. Chromium flows in environmental compartments. 
Table 5

Landscape properties used in this study

\begin{tabular}{|c|c|}
\hline Landscape properties & Taiwan \\
\hline Contaminated area $\left(\mathrm{m}^{2}\right)$ & $3.56 \mathrm{E}+10$ \\
\hline Annual average precipitation (m/d) & $8.22 \mathrm{E}-03$ \\
\hline Not currently used & $2.00 \mathrm{E}+01$ \\
\hline Flux; surface water into landscape (m/d) & $0.00 \mathrm{E}+00$ \\
\hline Land surface runoff $(\mathrm{m} / \mathrm{d})$ & $7.48 \mathrm{E}-03$ \\
\hline Atmospheric dust load $\left(\mathrm{kg} / \mathrm{m}^{3}\right)$ & $6.34 \mathrm{E}-08$ \\
\hline Dry deposition velocity, air particles (m/d) & $5.15 \mathrm{E}+02$ \\
\hline Aerosol organic fraction & $2.00 \mathrm{E}-01$ \\
\hline Volume fraction of water in leaf & $8.00 \mathrm{E}-01$ \\
\hline Volume fraction of air in leaf & $1.80 \mathrm{E}-01$ \\
\hline Volume fraction of lipid in leaf & $2.00 \mathrm{E}-03$ \\
\hline Volume fraction of water in stem & $7.00 \mathrm{E}-01$ \\
\hline Volume fraction of water in root & $8.50 \mathrm{E}-01$ \\
\hline Primary production dry vegetation $\left(\mathrm{kg} / \mathrm{m}^{2} / \mathrm{yr}\right)$ & $1.00 \mathrm{E}+00$ \\
\hline One-sided leaf area index & $6.00 \mathrm{E}+00$ \\
\hline Wet interception fraction & $1.00 \mathrm{E}-01$ \\
\hline Average thickness of leaf surface (cuticle) (m) & $6.00 \mathrm{E}-06$ \\
\hline Stem wet density $\left(\mathrm{kg} / \mathrm{m}^{3}\right)$ & $8.30 \mathrm{E}+02$ \\
\hline Leaf wet density $\left(\mathrm{kg} / \mathrm{m}^{3}\right)$ & $8.20 \mathrm{E}+02$ \\
\hline Root wet density $\left(\mathrm{kg} / \mathrm{m}^{3}\right)$ & $8.00 \mathrm{E}+02$ \\
\hline Vegetative attenuation factor, dry interception $\left(\mathrm{m}^{2} / \mathrm{kg}\right)$ & $2.90 \mathrm{E}+00$ \\
\hline Stomata area fraction (area stomata/area leaf) & $7.00 \mathrm{E}-03$ \\
\hline Effective pore depth & $2.50 \mathrm{E}-05$ \\
\hline Boundary layer thickness over leafs & $2.00 \mathrm{E}-03$ \\
\hline Leaf surface erosion half-life (d) & $1.40 \mathrm{E}+01$ \\
\hline Ground-water recharge $(\mathrm{m} / \mathrm{d})$ & $1.15 \mathrm{E}-04$ \\
\hline Evaporation of water from surface water $(\mathrm{m} / \mathrm{d})$ & $3.95 \mathrm{E}-03$ \\
\hline Thickness of the ground soil layer (m) & $1.00 \mathrm{E}-02$ \\
\hline Soil particle density $\left(\mathrm{kg} / \mathrm{m}^{3}\right)$ & $1.73 \mathrm{E}+03$ \\
\hline Water content in surface soil (vol. fraction) & $3.93 \mathrm{E}-01$ \\
\hline Air content in the surface soil (vol. fraction) & $2.85 \mathrm{E}-01$ \\
\hline Erosion of surface soil $\left(\mathrm{kg} / \mathrm{m}^{2} \mathrm{~d}\right)$ & $3.21 \mathrm{E}-05$ \\
\hline Bioturbation $\left(\mathrm{m}^{2} / \mathrm{d}\right)$ & $1.20 \mathrm{E}-04$ \\
\hline Thickness of the root-zone soil (m) & $7.94 \mathrm{E}-01$ \\
\hline Water content of root-zone soil (vol. fraction) & $2.08 \mathrm{E}-01$ \\
\hline Air content of root-zone soil (vol. fraction) & $2.47 \mathrm{E}-01$ \\
\hline Thickness of the vadose-zone soil (m) & $6.50 \mathrm{E}-01$ \\
\hline Water content; vadose-zone soil (vol. fraction) & $2.08 \mathrm{E}-01$ \\
\hline Air content of vadose-zone soil (vol. fraction) & $2.24 \mathrm{E}-01$ \\
\hline Thickness of the aquifer layer (m) & $3.00 \mathrm{E}+00$ \\
\hline Solid material density in aquifer $\left(\mathrm{kg} / \mathrm{m}^{3}\right)$ & $2.60 \mathrm{E}+03$ \\
\hline Porosity of the aquifer zone & $2.00 \mathrm{E}-01$ \\
\hline Fraction of land area in surface water & $4.41 \mathrm{E}-02$ \\
\hline Average depth of surface waters (m) & $1.41 \mathrm{E}+00$ \\
\hline Suspended sediment in surface water $\left(\mathrm{kg} / \mathrm{m}^{3}\right)$ & $2.28 \mathrm{E}-02$ \\
\hline Suspended sediment deposition $\left(\mathrm{kg} / \mathrm{m}^{2} / \mathrm{d}\right)$ & $1.05 \mathrm{E}+01$ \\
\hline Thickness of the sediment layer (m) & $5.00 \mathrm{E}-02$ \\
\hline Solid material density in sediment $\left(\mathrm{kg} / \mathrm{m}^{3}\right)$ & $2.60 \mathrm{E}+03$ \\
\hline Porosity of the sediment zone & $6.23 \mathrm{E}-01$ \\
\hline Sediment burial rate $(\mathrm{m} / \mathrm{d})$ & $1.00 \mathrm{E}-06$ \\
\hline Ambient environmental temperature (K) & $2.97 \mathrm{E}+02$ \\
\hline Surface water current $(\mathrm{m} / \mathrm{d})$ & $0.00 \mathrm{E}+00$ \\
\hline Organic carbon fraction in upper soil zone & $4.00 \mathrm{E}-02$ \\
\hline Organic carbon fraction in vadose zone & $4.02 \mathrm{E}-02$ \\
\hline Organic carbon fraction in aquifer zone & $4.00 \mathrm{E}-02$ \\
\hline Organic carbon fraction in sediments & $4.00 \mathrm{E}-02$ \\
\hline Boundary layer thickness in air above soil (m) & $5.00 \mathrm{E}-03$ \\
\hline Yearly average wind speed $(\mathrm{m} / \mathrm{d})$ & $7.50 \mathrm{E}+05$ \\
\hline
\end{tabular}

independent system. Second, the flows are in proportion to the economy scale, corresponding to population, resource consumed, energy consumed, product (power) generated, or size or number of factories (plants).
Table 7 shows the distribution of various chromium-relating industrial sources among the administrative divisions in Taiwan. The calculated flow described in Section 5.1 is redistributed to the administrative divisions according to the distribution of these source activities. A further simulation of the regional risk resulting from the bulk flow redistribution produces the results shown as Fig. 6. The divisions with deeper color are the areas with higher health risk. It is found that the areas with high chromium risk potential concentrates on the western part of Taiwan, because

Table 6

Human exposure factors used in this study

\begin{tabular}{|c|c|}
\hline human exposure factors & Taiwan \\
\hline Body weight (kg) & $6.03 \mathrm{E}+01$ \\
\hline Surface area $\left(\mathrm{m}^{2} / \mathrm{kg}\right)$ & $2.60 \mathrm{E}-02$ \\
\hline Active breathing rate $\left(\mathrm{m}^{3} / \mathrm{kg} \mathrm{h}\right)$ & $1.90 \mathrm{E}-02$ \\
\hline Resting breathing rate $\left(\mathrm{m}^{3} / \mathrm{kg} \mathrm{h}\right)$ & $6.40 \mathrm{E}-03$ \\
\hline Fluid intake (L/kg d) & $3.97 \mathrm{E}-02$ \\
\hline Fruit and vegetable intake $(\mathrm{kg} / \mathrm{kg} \mathrm{d})$ & $1.11 \mathrm{E}-02$ \\
\hline Grain intake $(\mathrm{kg} / \mathrm{kg} \mathrm{d})$ & $4.45 \mathrm{E}-03$ \\
\hline Milk intake (kg/kg d) & $2.54 \mathrm{E}-03$ \\
\hline Meat intake $(\mathrm{kg} / \mathrm{kg} \mathrm{d})$ & $3.33 \mathrm{E}-03$ \\
\hline Egg intake $(\mathrm{kg} / \mathrm{kg} \mathrm{d})$ & $7.61 \mathrm{E}-04$ \\
\hline Fish intake $(\mathrm{kg} / \mathrm{kg} \mathrm{d})$ & $1.87 \mathrm{E}-03$ \\
\hline Soil ingestion $(\mathrm{kg} / \mathrm{d})$ & $7.94 \mathrm{E}-07$ \\
\hline Breast milk ingestion by infants $(\mathrm{kg} / \mathrm{kg} \mathrm{d})$ & $1.10 \mathrm{E}-01$ \\
\hline Inhalation by cattle $\left(\mathrm{m}^{3} / \mathrm{d}\right)$ & $1.22 \mathrm{E}+02$ \\
\hline Inhalation by hens $\left(\mathrm{m}^{3} / \mathrm{d}\right)$ & $2.20 \mathrm{E}+00$ \\
\hline Ingestion of pasture, dairy cattle $(\mathrm{kg} / \mathrm{d})$ & $8.50 \mathrm{E}+01$ \\
\hline Ingestion of pasture, beef cattle $(\mathrm{kg} / \mathrm{d})$ & $6.00 \mathrm{E}+01$ \\
\hline Ingestion of pasture by hens $(\mathrm{kg} / \mathrm{d})$ & $1.20 \mathrm{E}-01$ \\
\hline Ingestion of water by dairy cattle (L/d) & $3.50 \mathrm{E}+01$ \\
\hline Ingestion of water by beef cattle $(\mathrm{L} / \mathrm{d})$ & $3.50 \mathrm{E}+01$ \\
\hline Ingestion of water by hens $(\mathrm{L} / \mathrm{d})$ & $8.40 \mathrm{E}-02$ \\
\hline Ingestion of soil by cattle $(\mathrm{kg} / \mathrm{d})$ & $4.00 \mathrm{E}-01$ \\
\hline Ingestion of soil by hens $(\mathrm{kg} / \mathrm{d})$ & $1.30 \mathrm{E}-05$ \\
\hline Fraction of water needs from ground water & $8.93 \mathrm{E}-02$ \\
\hline Fraction of water needs from surface water & $9.11 \mathrm{E}-01$ \\
\hline Water irrigation rate applied to agr. soil $\left(\mathrm{L} / \mathrm{m}^{2} \mathrm{~d}\right)$ & $2.50 \mathrm{E}-01$ \\
\hline Fraction fruits and vegetables that are exposed produce & $4.70 \mathrm{E}-01$ \\
\hline Fraction of fruits and vegetables local & $5.00 \mathrm{E}-01$ \\
\hline Fraction of grains local & $5.00 \mathrm{E}-01$ \\
\hline Fraction of milk local & $4.00 \mathrm{E}-01$ \\
\hline Fraction of meat local & $9.74 \mathrm{E}-01$ \\
\hline Fraction of eggs local & $4.00 \mathrm{E}-01$ \\
\hline Fraction of fish local & $5.00 \mathrm{E}-02$ \\
\hline Plant-air partition factor, particles $\left(\mathrm{m}^{3} / \mathrm{kg}\right)$ & $3.30 \mathrm{E}+03$ \\
\hline Rainsplash (mg/kg[plnt FM] $) /(\mathrm{mg} / \mathrm{kg}[$ dry soil $])$ & $3.40 \mathrm{E}-03$ \\
\hline Water use in the shower $(\mathrm{L} / \mathrm{min})$ & $8.00 \mathrm{E}+00$ \\
\hline Water use in the house $(\mathrm{L} / \mathrm{h})$ & $4.00 \mathrm{E}+01$ \\
\hline Room ventilation rate, bathroom $\left(\mathrm{m}^{3} / \mathrm{min}\right)$ & $1.00 \mathrm{E}+00$ \\
\hline Room ventilation rate, house $\left(\mathrm{m}^{3} / \mathrm{h}\right)$ & $7.50 \mathrm{E}+02$ \\
\hline Exposure time, in shower or bath $(\mathrm{h} / \mathrm{d})$ & $2.70 \mathrm{E}-01$ \\
\hline Exposure time, active indoors $(\mathrm{h} / \mathrm{d})$ & $1.50 \mathrm{E}+01$ \\
\hline Exposure time, outdoors at home $(\mathrm{h} / \mathrm{d})$ & $1.00 \mathrm{E}+00$ \\
\hline Exposure time, indoors resting $(\mathrm{h} / \mathrm{d})$ & $8.00 \mathrm{E}+00$ \\
\hline Indoor dust load $\left(\mathrm{kg} / \mathrm{m}^{3}\right)$ & $3.00 \mathrm{E}-08$ \\
\hline Exposure frequency to soil on skin, $(\mathrm{d} / \mathrm{yr})$ & $1.37 \mathrm{E}+02$ \\
\hline Soil adherence to skin $\left(\mathrm{mg} / \mathrm{cm}^{2}\right)$ & $5.00 \mathrm{E}-01$ \\
\hline Ratio of indoor gas conc. to soil gas conc. & $1.00 \mathrm{E}-04$ \\
\hline Exposure time swimming $(\mathrm{h} / \mathrm{d})$ & $5.00 \mathrm{E}-01$ \\
\hline Exposure frequency, swimming (d/yr) & $1.50 \mathrm{E}+01$ \\
\hline Water ingestion while swimming $(\mathrm{L} / \mathrm{kg} \mathrm{h})$ & $7.00 \mathrm{E}-04$ \\
\hline Exposure duration (yr) & $8.00 \mathrm{E}+01$ \\
\hline Averaging time $(\mathrm{d})$ & $2.56 \mathrm{E}+04$ \\
\hline
\end{tabular}


Table 7

The distribution of different chromium-related industrial sources among the administrative divisions in Taiwan

\begin{tabular}{|c|c|c|c|c|c|c|c|c|}
\hline & Leather $(\%)$ & Stainless steel $(\%)$ & Refractory (\%) & Ferrochrome $(\%)$ & Cr-alloy (\%) & Dyeing (\%) & Power plant $(\%)$ & Incinerator $(\%)$ \\
\hline Taipei City & 0.0 & 0.0 & 4.6 & 0.0 & 0.0 & 0.0 & 0.0 & 15.0 \\
\hline Keelung City & 0.0 & 0.0 & 0.0 & 0.0 & 0.0 & 0.0 & 7.9 & 0.0 \\
\hline Hsinchu City & 0.0 & 0.0 & 3.1 & 0.0 & 1.8 & 0.2 & 0.0 & 5.0 \\
\hline Taipei County & 6.8 & 7.1 & 26.2 & 40.0 & 21.1 & 27.6 & 5.2 & 15.0 \\
\hline Yilan County & 0.0 & 0.0 & 0.0 & 0.0 & 0.0 & 0.2 & 0.0 & 5.0 \\
\hline Taoyuan County & 7.7 & 28.6 & 7.7 & 20.0 & 7.0 & 41.0 & 19.2 & 0.0 \\
\hline Hsinchu County & 0.0 & 7.1 & 1.5 & 0.0 & 0.0 & 1.7 & 2.4 & 0.0 \\
\hline Taichung City & 0.0 & 0.0 & 3.1 & 0.0 & 7.0 & 0.6 & 0.0 & 5.0 \\
\hline Miaoli County & 1.7 & 0.0 & 3.1 & 0.0 & 0.0 & 0.9 & 6.8 & 0.0 \\
\hline Taichung County & 6.0 & 14.3 & 4.6 & 20.0 & 12.3 & 5.2 & 18.6 & 5.0 \\
\hline Changhua County & 8.5 & 0.0 & 9.2 & 0.0 & 12.3 & 11.6 & 1.9 & 5.0 \\
\hline Nantou County & 6.0 & 0.0 & 0.0 & 20.0 & 0.0 & 0.2 & 0.0 & 0.0 \\
\hline Yunlin Conty & 9.4 & 0.0 & 1.5 & 0.0 & 0.0 & 3.2 & 7.1 & 0.0 \\
\hline Chiayi City & 1.7 & 0.0 & 0.0 & 0.0 & 0.0 & 0.2 & 0.0 & 5.0 \\
\hline Tainan City & 2.6 & 0.0 & 1.5 & 0.0 & 14.0 & 0.6 & 0.0 & 5.0 \\
\hline Kaoshiung City & 0.9 & 7.1 & 3.1 & 0.0 & 5.3 & 0.0 & 3.4 & 5.0 \\
\hline Chiayi County & 3.4 & 0.0 & 1.5 & 0.0 & 1.8 & 0.3 & 0.0 & 5.0 \\
\hline Tainan County & 28.2 & 14.3 & 4.6 & 0.0 & 14.0 & 5.9 & 0.0 & 5.0 \\
\hline Kaoshiung County & 14.5 & 21.4 & 16.9 & 0.0 & 3.5 & 0.6 & 27.4 & 15.0 \\
\hline Pingtung County & 2.6 & 0.0 & 7.7 & 0.0 & 0.0 & 0.0 & 0.0 & 5.0 \\
\hline Taitung County & 0.0 & 0.0 & 0.0 & 0.0 & 0.0 & 0.2 & 0.0 & 0.0 \\
\hline Hualien County & 0.0 & 0.0 & 0.0 & 0.0 & 0.0 & 0.0 & 0.0 & 0.0 \\
\hline
\end{tabular}

of the intense chromium-related activities in the part of Taiwan. 18 of the 23 divisions have risks above the traditional acceptable levels, $10^{-6}$ in terms of cancer risk and 1 in terms of HQ. Kaohsiung City and Taoyuan County are the top two highest risk regions $\left(8.6 \times 10^{-5}\right.$ and $4.8 \times 10^{-5}$ in terms of carcinogenic risk, respectively; 55 and 37 in terms of $\mathrm{HQ}$, respectively), because Kaohsiung City has the highest density of stainless steel factories and the second highest density of refractory factories; Taoyuan County has the largest number of stainless steel factories.

\subsection{Discussion of errors}

The result is not exactly the real situation but rather is an approximate image of the reality. Mostly due to limitation of data availability and assumptions made in this study, there are errors associated with the assessment results. The source of errors includes the following:

(1) Unregistered or missing data: some commodities are not forced to register in detail and cannot be found in the statistics, and some illegal operations of $\mathrm{Cr}$-containing materials may have taken place. The real substance flow rate may thus be higher than the estimated flow rate.

(2) Measurement errors: measurement is involved in quantifying water flow, concentrations of $\mathrm{Cr}$ in water bodies and ash, and release of $\mathrm{Cr}$ from landfilled waste and solidified sludge. It is not clear whether measurement errors lead to over- or under-estimation.

(3) Use of data transferred from other nations: several parameters needed to calculate the substance flow are not available, so data in the literature that have been developed for different nations are used, including air emission factors, chromium contents in several commodity items, and chromium speciation in the environment.
(4) The simplifications and assumptions made in the modeling method: model and parameter uncertainty associated with the use of CalTOX risk assessment model will

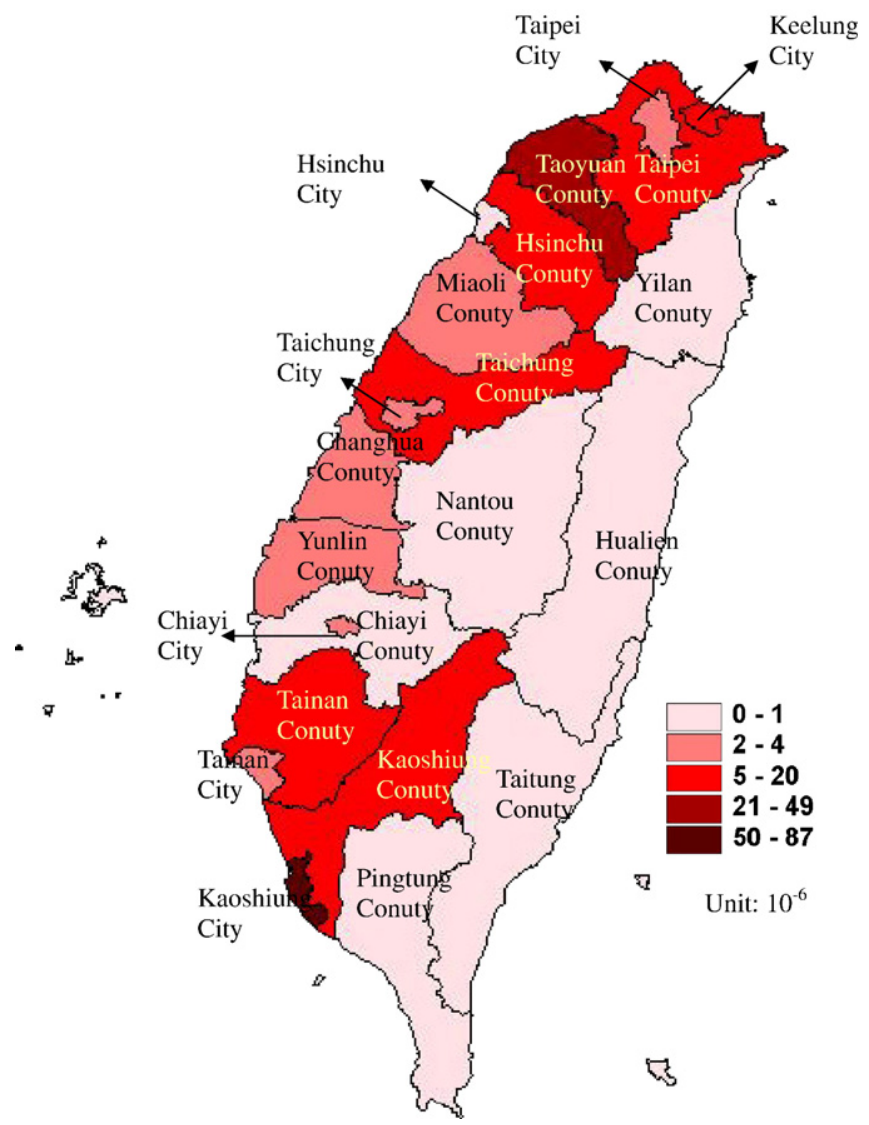

Fig. 6. The risk distribution of chromium among the administrative divisions in Taiwan. The divisions with deeper color are the areas with higher health risk. 
contribute to the total errors. In addition, the distribution of substance flow among the administrative divisions is based on the assumptions of flow's proportionality with industrial activities and independence between divisions.

A preliminary sensitivity analysis conducted for the CalTOX model used in risk calculations shows that the most sensitive parameters of influencing the risk estimations are the following: evaporation of water from surface water, annual average precipitation, contaminated area, breathing rate, and fruit and vegetable intake rate. The sensitivity analysis is calculated as the relative change of risk $(\Delta Y / Y)$ in reaction to a change of parameter $(\Delta \mathrm{Xi} / \mathrm{Xi})$. In order to examine the uncertainty systematically to identify key sources of uncertainty and deliver complete risk information, it is suggested that the statistical distributions of the input variables and parameters be determined and then the Monte Carlo simulations be performed to derive the uncertainty distribution of the risk estimates.

\section{Conclusions}

This study has demonstrated an integrated risk assessment method. Integration of SFA and HRA enables the system boundary of HRA to be expanded from single process to multiple processes. The integration of the two analysis methods conveys a bigger picture than the traditional risk assessment does and brings out additional information that is valuable for efficient substance management. The total risks resulting from the substance cycle can be sketched, and the sources, activities, and paths related to the life stages of a substance that plays key roles to the resultant risk can be identified. The substance management can be designed more efficiently when such a comprehensive understanding of risk is obtained.

Although the data requirements required in this approach are relatively less than those required if the traditional approach is used to assess the risks of individual sources and the to obtain the total risks by aggregating risks from all kinds of sources, there is still a lot of information needed. The data regarding the substance-containing commodities statistics, the compositions of concerned substances in the commodities, and the residence time of commodities in the economy, and the emission and discharge characteristics from the life stages of the commodities should be made more accurate and complete. The present study is dedicated to presentation of the systemic methodology; in the future proper uncertainty analysis may be conducted to facilitate planning of information collection.

\section{Nomenclature}

$\mathrm{ADD}_{m n}$ Average daily dose from exposure medium $m$ (drinking water, food, etc.) and exposure route $n$ (inhalation, ingestion, or dermal absorption) $(\mathrm{mg} / \mathrm{kg} \mathrm{d})$

AT Averaging time; period over which exposure is averaged (d)
BW Body weight $(\mathrm{kg})$

$\mathrm{C}_{\mathrm{Cr}(\mathrm{Cu}, \mathrm{Pb}) \text { sludge }}$ The concentration of $\mathrm{Cr}$ contained in $\mathrm{Cr}(\mathrm{Cu}$, $\mathrm{Pb})$ sludge $(\mathrm{kg} / \mathrm{kg})$

$C_{i}$ ( $i=$ fly ash, bottom ash) The concentration of $\mathrm{Cr}$ in incinerator fly ash (bottom ash, landfilled waste) (t)

$C_{m} \quad$ Cr concentration in the exposure medium $m\left(\mathrm{mg} / \mathrm{m}^{3}\right.$, $\mathrm{mg} / \mathrm{L}$, and $\mathrm{mg} / \mathrm{kg}$ for air, water, and food, respectively)

$E_{i}(i=$ coal, oil) The power generated from coal plants (oil plants) (GJ)

ED Exposure duration (yr)

EF Exposure frequency $(\mathrm{d} / \mathrm{yr})$

$\mathrm{EF}_{i}(i=$ ferrochrome, stainless steel, refractory, incinerator, coal, oil) The emission factor of $\mathrm{Cr}$ of ferrochrome (stainless steel, refractory, incinerator, in unit of ton/ ton; coal plants, oil plants, in unit of ton/GJ)

$\mathrm{IU}_{m n} \quad$ Contact rate; the amount of exposure medium contacted per unit time or event $\left(\mathrm{m}^{3} / \mathrm{d}, \mathrm{L} / \mathrm{d}\right.$, and $\mathrm{kg} / \mathrm{d}$ for air, water, and food, respectively)

$N^{i} \quad$ The number of kinds of heavy metals in the $i$ th type of sludge

$P_{i}$ ( $i=$ ferrochrome, stainless steel, refractory) The amount of production of ferrochrome (stainless steel, refractory) ( $t$ )

$Q_{i}$ ( $i=$ ferrochrome, stainless steel, refractory, incinerator, coal, oil) The air emissions of $\mathrm{Cr}$ from ferrochrome (stainless steel, refractory, incinerator, coal plant, oil plant) (t)

$Q_{\text {flow rate }}^{j}$ The flow rate of $\mathrm{Cr}$ of the $j$ th river $\left(\mathrm{m}^{3} / \mathrm{s}\right)$

$C_{\text {soluble }}^{j}$ The soluble $\mathrm{Cr}$ concentration of the $j$ th river $(\mathrm{g} / \mathrm{L})$

$Q_{\text {surface water }}^{j}$ The discharge of $\mathrm{Cr}$ to surface water: the $j$ th river $(\mathrm{kg} / \mathrm{yr})$

$Q_{\text {flow rate }}$ The total discharge of $\mathrm{Cr}$ to surface water $(\mathrm{kg} / \mathrm{yr})$

$Q_{\text {sludge }}^{i}$ The amount of $\mathrm{Cr}$ contained in the $i$ th type of sludge ( $\left.\mathrm{t}\right)$

$Q_{\text {sludge }}$ The total amount of Cr contained in sludge ( $\mathrm{t}$ )

$S_{i}$ ( $i=$ fly ash, bottom ash, landfill) The amount of $\mathrm{Cr}$ contained in incinerator fly ash (bottom ash, landfilled waste) (t)

$T \quad$ Duration $(365 \times 24 \times 60 \times 60 \mathrm{~s})$

$W_{i}((i=$ fly ash, bottom ash, landfill $)$ The amount of incinerator

fly ash (bottom ash, landfilled waste) (t)

$W_{\text {burn waste }}$ The amount of waste incinerated ( $\mathrm{t}$ )

$W_{\text {sludge }}^{i}$ The amount of the $i$ th type of registered sludge ( $\mathrm{t}$ )

$X_{\mathrm{Cr}(\mathrm{Cu}, \mathrm{Pb})}\{1$, if $\mathrm{Cr}(\mathrm{Cu}, \mathrm{Pb})$ contained in sludge 0 , otherwise

\section{References}

Agency for Toxic Substances and Disease Registry (ATSDR). Toxicological profile for chromium. Atlanta, GA: U.S. Dept of Health and Human Services, Public Health Service; 2000.

Agency for Toxic Substances and Disease Registry (ATSDR). Priority List of Hazardous Substances. Available through the Internet at http://www.atsdr. cdc.gov/cercla/05list.html 2005.

Ayres Robert U, Ayres Leslie W. Industrial ecology towards closing the material cycle. Edward Elgar; 1996.

Baccini P, Brunner PH. Metabolism of the anthroposphere. New York: Springer; 1991.

Bureau of Foreign Trade. Taiwan, Import and Export Statistics. Available through the Internet at http://cus93.trade.gov.tw/fsci/ 2005.

Burrows D, Adams RM. Occupational skin disease. In: Adams RM, editor. 2nd ed. Philadelphia: W.B. Saunders; 1990. p. 349-86.

Brunner PH, Rechberger H. Practical handbook of material flow analysis. Boca Raton: Lewis Publishers; 2003 
Danish EPA. Mass flow analysis of chromium and chromium compoundsenvironmental project, vol. 793; 2003.

DTSC. Department of Toxic Substances Control, "CalTOX, A Multimedia Total-Exposure Model for Hazardous-Waste Sites. Part I: Executive Summary, and Part II: The Dynamic Multimedia Transport and Transformation Model, and Part III: The Multiple-Pathway Exposure Model. Prepared for the state of California, Department of Toxic Substances Control", Lawrence Livermore National Laboratory, Livermore, CA URCRL-CR-111456; 1993.

Fishbein L. Source Transport and alterations of metal compounds: an overview. Arsenic, beryllium, cadmium, chromium and nickel, environ health perspective, 40. ; 1981. p. 43-64.

Government of Canada, Chromium and its compounds. In Canadian Environmental Protection Act. Priority substances list assessment report, Ottawa, Ontario: Government of Canada, Minister of Supply and Services Canada; 1994.

Graedel TE, van Beers D, Bertram M, Fuse K, Gordon RB, Gritsinin A, et al. Multilevel cycle of anthropogenic copper. Environ Sci Technol 2004;38:1242-52.

Graedel TE, Bertram M, Reck B. Exploratory data analysis of the multilevel anthropogenic zinc cycle. J Ind Ecol 2005a;9:91-108.

Graedel TE, van Beers D, Bertram M, Fuse K, Gordon RB, Gritsinin A, et al. The multilevel cycle of anthropogenic zinc. J Ind Ecol 2005b;9:67-90.

Guin'ee JB, van den Burgh JCJM, Boelens J, Fraanje PJ, Huppes G, Kandelaars PPAAH. Evaluation of risks of metal flows and accumulation in economy and environment. Ecol Econ 1999;30:47-65.

Hawkins TR, Matthews HS, Hendrickson C. Closing the loop on cadmium - an assessment of the material cycle of cadmium in the US. Int $\mathrm{J}$ Life Cycle Assess 2006;11:38-48.

IDB. Industry Database. Available through the Internet at http://www.itis.org. tw/cgi-bin/websql/websql.dir/app/ioweb/psspfm.hts 2006.

Johnson J, Jirikowic J, Bertram M, Van Beers D, Gordon RB, Henderson K, et al. Contemporary anthropogenic silver cycle: a multilevel analysis. Environ Sci Technol 2005;39:4655-65.

Kleijn R. IN=OUT: the trivial central paradigm of MFA. J Ind Ecol 1999;3:8-10.

Lanzano T, Bertram M, De Palo M, Wagner C, Zyla K, Graedel TE. The contemporary European silver cycle. Resour Conserv Recycl 2006;46:27-43.

Lindqvist A, von Malmborg F. What can we learn from local substance flow analyses? - the review of cadmium flows in Swedish municipalities. J Clean Prod 2004;12:909-18.

Ma HW. Stochastic multimedia risk assessment for a site with contaminated groundwater. Stoch Environ Res Risk Assess 2002;16:464-78.

Ma HW, Lai YL, Chan CC. Transfer of dioxin risk between nine major municipal waste incinerators in Taiwan. Environ Int 2002;28:103-10.
National Research Council (NRC). Risk assessment in the Federal Government: managing the process. NAS-NRC committee on the institutional means for assessment of risks to public health. Washington, DC: National Academy Press; 1983.

Newhook R, Hirtle H, Byrne K, Meek ME. Releases from copper smelters and refineries and zinc plants in Canada: human health exposure and risk characterization. Sci Total Environ 2003;301:23-41.

Palm V, Ostlund C. Lead and zinc flows from technosphere to biosphere in a city region. Sci Total Environ 1996;192:95-109.

Polak L. Immunology of chromium. In: Burrows D, editor. Chromium: metabolism and toxicity. Boca Raton, FL: CRC Press; 1983. p. 51-135.

Spatari S, Bertram M, Fuse K, Graedel TE, Rechberger H. The contemporary European copper cycle: 1 year stocks and flows. Ecol Econ 2002;42:27-42.

Spatari S, Bertram M, Fuse K, Graedel TE, Shelov E. The contemporary European zinc cycle: 1-year stocks and flows. Resour Conserv Recycl 2003;39:137-60

Spatari S, Bertram M, Gordon RB, Henderson K, Graedel TE. Twentieth century copper stocks and flows in North America: a dynamic analysis. Ecol Econ 2005;54:37-51.

Taiwan EPA. A leaching model for assessing solidification of industrial waste sludge containing heavy metals; 2002.

Taiwan EPA. Soil and Groundwater Remediation Web. Available through the Internet at http://ww2.epa.gov.tw/soilgw/en/index.htm 2006.

Taiwan EPA. Industrial Waste Control Center Report System. Available through the Internet at http://waste.epa.gov.tw/prog/indexFrame.asp 2006.

U.S. Environmental Protection Agency (U.S. EPA). Locating and estimating air emissions from sources of chromium. United States Office of Air Quality Planning and Standards; 1984.

U.S. Environmental Protection Agency (U.S. EPA). Human health and ecological risk assessment support to the development of technical standards for emission from combustion units burning hazardous wastes: background document; 1999.

van Beers D, Bertram M, Fuse K, Spatari S, Graedel TE. The contemporary African copper cycle: one year stocks and flows. J S Afr Inst Min Metall 2003;103:147-62.

Van der voet E, Vanegmond L, Kleijn R, Huppes G. Cadmium in the Europeancommunity - a policy-oriented analysis. Waste Manage Res 1994;12:507-26.

Van der Voet E, Van Oers L, Guinee JB, de Haes HAU. Using SFA indicators to support environmental policy. Environ Sci Pollut Res 1999;6:49-58.

Vexler D, Bertram M, Kapur A, Spatari S, Graedel TE. The contemporary Latin American and Caribbean copper cycle: 1 year stocks and flows. Resour Conserv Recycl 2004;41:23-46. 